\title{
Article
}

\section{An Initiative to Broaden Diversity in Undergraduate Biomathematics Training}

\author{
Gregory Goins, ${ }^{*}$ Mingxiang Chen, ${ }^{+}$Catherine White, ${ }^{*}$ Dominic Clemence, ${ }^{+}$ \\ Thomas Redd, ${ }^{+}$and Vinaya Kelkar*
}

*Department of Biology and 'Department of Mathematics, North Carolina A\&T State University, Greensboro, NC 27411

Submitted March 17, 2010; Revised June 10, 2010; Accepted June 11, 2010

Monitoring Editor: John Jungck

\begin{abstract}
At North Carolina A\&T State University (NCATSU), there was a critical need to better coordinate genuine research and classroom experiences for undergraduates early in their academic career. We describe the development and implementation of a faculty alliance across academic departments to increase biomathematics research opportunities for underrepresented minorities. Our faculty alliance is called the Integrative Biomathematical Learning and Empowerment Network for Diversity (iBLEND). The fundamental purpose of the iBLEND alliance was to inspire underrepresented minorities to pursue research careers by increasing the visibility of research conducted at the interface of mathematics and biology at NCATSU. Because of the many positive impacts, iBLEND gained significant buy-in from administration, faculty, and students by 1) working from the ground up with administration to promote campus-wide biomathematics research and training, 2) fostering associations between research and regular undergraduate academic courses, 3 ) creating and disseminating biomathematics teaching and learning modules, and 4) enhancing learning community support at the interface of mathematics and biology. Currently, iBLEND is viewed as a productive site for graduate schools to recruit underrepresented minority students having specific competencies related to mathematical biology.
\end{abstract}

\section{INTRODUCTION}

For the nation as a whole, overcoming minority underrepresentation in bioscience and mathematics career fields represents a major challenge (National Research Council [NRC], 2007). Across the nation, many generalized programs have focused on retention of minority students in the sciences with varying degrees of success (McElroy and Armesto, 1998). African Americans, in particular, remain significantly underrepresented when compared with the percentage of majority undergraduates who go on to pursue graduate degrees and professional career fields in science and mathematics (Mervis, 2003). North Carolina Agricultural and

DOI: $10.1187 /$ cbe.10-03-0043

Address correspondence to: Gregory D. Goins (gdgoins@ncat.edu).

(C) 2010 G. Goins et al. CBE-Life Sciences Education () 2010 The American Society for Cell Biology. This article is distributed by The American Society for Cell Biology under license from the author(s). It is available to the public under an AttributionNoncommercial-Share Alike 3.0 Unported Creative Commons License (http://creativecommons.org/licenses/by-nc-sa/3.0).
Technical State University (NCATSU) is a historically minority-serving land-grant institution located in Greensboro, NC, with an overall enrollment of approximately 10,000 undergraduates. NCATSU is among the nation's leading institutions that award baccalaureate degrees to African Americans majoring in STEM disciplines. Although NCATSU is the largest historically black college and university (HBCU) in North Carolina, overcoming underrepresentation in biology and mathematics remains a difficult challenge (Moses and Cobb, 2001). Paradoxically, this challenge exists despite expanding career opportunities in industry, academia, and government for those skilled at the intersection of biology and mathematics (NRC, 2003). Because quantitative approaches dominate the forefront of modern research, there is an urgent national need to prepare undergraduates for careers and further academic work in the fields at the intersection of the biological and mathematical sciences (NRC, 2003). To be competitive for future careers at the intersection of mathematics and biology, undergraduates need to make explicit connections between these disciplines (Gross, 1994; Jungck, 2005).

Although NCATSU intensely competes for the same limited pool of high-achieving students as other institutions 
Table 1. High school rank of 2009 entering NCATSU freshmen (average SAT $=903$ )

\begin{tabular}{lcccccc}
\hline $\begin{array}{c}\text { Top } \\
\text { fifth }\end{array}$ & $\begin{array}{c}\text { Second } \\
\text { fifth }\end{array}$ & $\begin{array}{c}\text { Third } \\
\text { fifth }\end{array}$ & $\begin{array}{c}\text { Fourth } \\
\text { fifth }\end{array}$ & $\begin{array}{c}\text { Bottom } \\
\text { fifth }\end{array}$ & $\begin{array}{c}\text { Not } \\
\text { available }\end{array}$ & Total \\
\hline 331 & 475 & 523 & 355 & 47 & 167 & 1,898 \\
$17 \%$ & $25 \%$ & $28 \%$ & $19 \%$ & $3 \%$ & $9 \%$ & $100 \%$
\end{tabular}

Data (2010) published within NCATSU factbook http://qed. ncat.edu.

encouraging students to work at the interface of math and, biology was a challenging task. Given NCATSU's mission as a land-grant HBCU, our entering freshmen are admitted having a wide range of prior high school success (Table 1). Our biology majors have traditionally avoided quantitative disciplines such as mathematics, and conversely, mathematics majors do not always see relevance or applications of their skills to the life sciences. Nonetheless we recognized that if NCATSU biology and mathematics undergraduates were to remain competitive, more insightful cross-departmental programs were needed on our campus to reverse trends.

Both the Departments of Biology and Mathematics had limited full scholarships available, which can make recruitment of high-caliber students a significant challenge. Also, more than $90 \%$ of our students received some form of financial aid, and for a myriad of reasons a significant number of our early undergraduates sought nonacademic outside jobs. Therefore, stipend support was needed to significantly quell the need for outside nonacademic employment, allowing students to dedicate their time to becoming more competitive for graduate degree programs (NRC, 2007). Acquisition of grant funding (Table 2) and provision of stipends was key to entice undergraduates to maintain scholarly focus and not seek competing interests such as off-campus nonacademic related employment.

Here we describe the development and implementation of an instructional alliance that linked high-quality faculty interactions, excellent teaching, strong interdisciplinary training, and high-quality biomathematics-related research. Ultimately, the hope was to channel a greater number of mathematics and biology undergraduates who go on to earn the $\mathrm{Ph}$. D. We were particularly interested in exploring ways to translate biomathematical concepts into meaningful experiences for our undergraduates.

\section{RESULTS AND DISCUSSION}

\section{Modest Beginnings Spurred Positive Growth}

In 2003, motivated by the fervor associated with the emergence of high-throughput genomics, a small group of senior and junior mathematicians and biologists formed an alliance (<6 members in 2003) at NCATSU. These faculty taught freshman courses, were familiar with retention rate data for 2001 through 2005 (Tables 3 and 4), and wanted to broaden bio-math-related career goals for undergraduates thorough earlier exposure and research experiences. In essence, it is important to note that these faculty members were essen-
Table 2. Biomathematics-related research, mentoring, and teaching capacity-building activities and events for undergraduates (20032009)

\begin{tabular}{|c|c|c|}
\hline Funding source & Programs & Acronym \\
\hline $\begin{array}{l}\text { Burroughs Wellcome } \\
\text { Fund }\end{array}$ & Students Hot on Sciences & SHOTS \\
\hline Glaxo-Smith-Kline & $\begin{array}{l}\text { Retention Initiative for } \\
\text { Students in the } \\
\text { Biological Sciences }\end{array}$ & RSBS \\
\hline $\begin{array}{l}\text { N.C. A\&T } \\
\text { Administration }\end{array}$ & $\begin{array}{l}\text { Biological Summer } \\
\text { Undergrad Research } \\
\text { Experience } \\
\text { Symposium }\end{array}$ & BSURE \\
\hline $\begin{array}{l}\text { N.C. A\&T } \\
\text { Administration }\end{array}$ & $\begin{array}{l}\text { Life and Physical } \\
\text { Sciences Symposium }\end{array}$ & LPSS \\
\hline $\mathrm{NIH}$ & $\begin{array}{l}\text { Research Infrastructure } \\
\text { in Minority } \\
\text { Institutions }\end{array}$ & RIMI \\
\hline $\mathrm{NIH}$ & $\begin{array}{l}\text { NIH RISE Retention } \\
\text { Initiative for Scientific } \\
\text { Enhancement }\end{array}$ & RISE \\
\hline NSF UBM & $\begin{array}{l}\text { Interdisciplinary } \\
\text { Training for } \\
\text { Undergraduates in } \\
\text { Biological and } \\
\text { Mathematical Sciences }\end{array}$ & UBM-iBLEND \\
\hline $\mathrm{NIH}$ & $\begin{array}{l}\text { Minority Access to } \\
\text { Research Careers }\end{array}$ & $\begin{array}{l}\text { MARC-U } \\
\text { STAR }\end{array}$ \\
\hline MERCK/AAAS & $\begin{array}{l}\text { Undergraduate Science } \\
\text { Research Program }\end{array}$ & MERCK \\
\hline
\end{tabular}

tially very early adopters toward a biomathematics focus on our campus. With support from their respective mathematics and biology department chairs, these faculty members came together at informal meetings and began to share their visions and map out new strategies to overcome these challenges. The early cross-departmental meetings served as brainstorming forums to amplify cross-departmental measures that could better connect undergraduates and other faculty with interactions between biology and mathematics. From these small meetings, an alliance emerged of like-

Table 3. Retention rates (\%) for freshman biology major cohorts at NCATSU before (2001-2005) and after (2006-2008) crossdepartmental initiatives.

\begin{tabular}{lcccccr}
\hline Year & $\begin{array}{c}\text { Freshman } \\
\text { cohort } \\
\text { No. }\end{array}$ & $\begin{array}{c}1 \\
\mathrm{yr}\end{array}$ & $\begin{array}{c}2 \\
\mathrm{yr}\end{array}$ & $\begin{array}{c}3 \\
\mathrm{yr}\end{array}$ & $\begin{array}{c}4 \\
\mathrm{yr}\end{array}$ & $\begin{array}{c}5 \\
\mathrm{yr}\end{array}$ \\
\hline 2001 & 67 & 64 & 58 & 49 & 22 & 3 \\
2002 & 76 & 76 & 65 & 59 & 30 & 7 \\
2003 & 100 & 68 & 58 & 51 & 27 & 6 \\
2004 & 105 & 74 & 47 & 47 & 34 & 12 \\
2005 & 69 & 71 & 65 & 58 & 38 & \\
2006 & 93 & 72 & 53 & 51 & & \\
2007 & 77 & 75 & 65 & & & \\
2008 & 92 & & & & & \\
\hline
\end{tabular}

Data (2010) published within NCATSU factbook http://qed. ncat.edu. 
Table 4. Retention rates (\%) for freshman math major cohorts at NCATSU before (2001-2005) and after (2006-2008) cross-departmental initiatives.

\begin{tabular}{lcccccr}
\hline Year & $\begin{array}{c}\text { Freshman } \\
\text { cohort } \\
\text { No. }\end{array}$ & $\begin{array}{c}1 \\
\mathrm{yr}\end{array}$ & $\begin{array}{c}2 \\
\mathrm{yr}\end{array}$ & $\begin{array}{c}3 \\
\mathrm{yr}\end{array}$ & $\begin{array}{c}4 \\
\mathrm{yr}\end{array}$ & $\begin{array}{c}5 \\
\mathrm{yr}\end{array}$ \\
\hline 2001 & 16 & 81 & 56 & 63 & 31 & 19 \\
2002 & 21 & 71 & 67 & 57 & 29 & 10 \\
2003 & 18 & 72 & 67 & 67 & 44 & 6 \\
2004 & 11 & 82 & 73 & 73 & 64 & 18 \\
2005 & 18 & 67 & 61 & 61 & 50 & \\
2006 & 13 & 61 & 62 & 46 & & \\
2007 & 15 & 73 & 53 & & & \\
2008 & 21 & 76 & & & & \\
\hline
\end{tabular}

Data (2010) published within NCATSU factbook http://qed. ncat.edu.

minded faculty. Beginning in 2005, the alliance led to expanded and diverse undergraduate learning experiences and several funded campus-wide initiatives (Table 2) to enhance research and teaching capabilities. This change represented a fundamental shift that positively affected the educational and research environments at NCATSU. Both the Departments of Biology and Mathematics collectively and individually have instituted several key measures that have increased the on-campus visibility of laboratory-based research for undergraduates. These measures that have increased undergraduate research and research training include:

- Collective faculty conceptualization and crafting of grant proposals

- Emphasis on faculty and student development in research and pedagogy

- Provision of departmental retreats and meetings that foster new ideas

- Emphasis on freshman orientations specific for science majors

- Distribution of shared documents through centralized computer servers

- Broadening team-taught courses and research contributions

- Providing weekly seminars and annual scientific research symposia

This new synergistic alliance of biology and mathematics faculty members became known as the Integrative Biomathematics Learning and Empowerment Network for Diversity (iBLEND: http://blend.ncat.edu). The formation of the iBLEND alliance was not only due to effective coordination of activities between biology and mathematics faculty. iBLEND sought to increase minority participation in biomathematics research through a broadly based program for undergraduate students at NCATSU. The driver of iBLEND was the notion of infusing biomathematical models within laboratory and classroom activities. One essential component was special attention to the mutual recognition of the complementary expertise of alliance members. Since 2003, the overarching goal of iBLEND has been to encourage, enable, and support students to accomplish research at the interface of mathematics and biology. This goal was achieved by long-term immersion of students in cuttingedge research activities, coupled with close curricular ties, support, academic and career mentoring, and training activities among the Mathematics, Biology, and General Education Departments at NCATSU.

\section{Key Organizational Structure and Institutional Endorsements}

At approximately the same time the iBLEND alliance was forming, the Carnegie Foundation classification for NCATSU was upgraded to the high-research activity category (Carnegie Classification, 2005). This enhanced research focus positively affected the educational and research environments at NCATSU, increasing support from the administration for expanding undergraduate learning experiences that would contribute to more students seeking advanced mathematics and bioscience degrees. As a result, several campus-wide initiatives were successful in securing research and teaching capacity-building grant funding resources (Table 2). Support was channeled particularly to improving NCATSU core capabilities needed to better prepare undergraduates for cutting-edge research careers at the interface of mathematics and biology. Particularly important was support that fostered immediate increases in genomic bench research and teaching resources, followed by hiring of faculty and personnel staffing with biomathematical experience portfolios. Under this enabling campus-wide environment, the iBLEND alliance was able to successfully secure specific funding that fostered a real bridge between the Biology and Mathematics Departments. A formal connection across these traditional academic departments provided a significant complement to existing academic and research programs at NCATSU, where undergraduates are being exposed to cutting-edge biomathematics research.

NCATSU enhanced biomathematics training opportunities by:

- Increasing collaboration between our genomics and computational biology research laboratories

- Developing curricular coherence, concept mapping, and mutual reinforcement between research and classroom activity

- Instituting collaborative mentoring networks for research, learning, and teaching at the interfaces between the sciences and mathematics

By leveraging our recent surge of competitive research activity (Table 2), innovative instruction, and collaboration, the iBLEND advanced our transformation to the next level by establishing a broader bridge for our undergraduates at the interface of mathematics and biology. The iBLEND represents a proactive, intensive approach to bridge campus chasms by positively influencing academic programs through interdisciplinary training and strong evaluation and assessments. The iBLEND project also has significant spillover effects for our university by developing new interdisciplinary collaborations that benefit our students. Examples include recent undergraduate research and training 
success outcomes through several federal programs from the National Science Foundation (NSF) and the National Institutes of Health (NIH). In addition, we received significant private and corporate grant awards from Merck, Inc, The Burroughs Wellcome Fund, and the GlaxoSmithKline Foundation (Table 2). These awards support student stipends and salaries as well as provide funding for books and computers. To complement our scholarship programs, the Department of Biology established a $\$ 1$ million endowed scholarship fund through its alumni. Earnings from this fund allowed the department to pay tuition, fees, and book vouchers for deserving students. Another prime example is the Merck/AAAS Undergraduate Science Research Program, which supported undergraduate biology and chemistry majors as they conducted summer research and coauthored scientific presentations and publications with faculty in the Departments of Biology and Chemistry. As a culminating event for their undergraduate research, the A\&T sponsors the Summer Undergraduate Research Experience (BSURE) symposium focusing on careers in the biomedical and behavioral sciences, development of traits and skills necessary to be successful in science and other careers, and the rewards of a career in science.

\section{Collaboration between Genomics and Computational Biology Research Laboratories}

Our Biotechnology, Biosciences, and Computational Science core laboratories provided students with cross-cutting visualization, modeling, simulation, and analyses for our biomathematics program. Starting in 2004, NCATSU was awarded a capacity-building Research Infrastructure in Minority Institutions (RIMI) grant from the National Center for Minority Health and Health Disparities (Table 2) that supported a centrally located Molecular Genetics, Genomics, and Proteomics core lab. The purpose of the core lab was to provide interdisciplinary research and training that emphasized detailed mathematical analysis combined with tools from molecular biology and genetics. The core laboratory included molecular biologists and computational bio-physicists involved in laboratory research. The core laboratory served as a training ground for faculty and students to learn new techniques including phenotype microarray analysis, DNA sequencing, and RT-PCR.

Our shared Genomics and Computational Core Laboratory Clusters (housed in the same buildings as the Mathematics and Biology Departments) provided a natural opportunity for our undergraduates to fuse conceptual understanding among research, classroom activity, and science retention initiatives. The strong interdisciplinary research and training projects in our Core Labs are built on research strengths of faculty in the Departments of Biology and Mathematics enriched with CoPI collaborations with neighbor R1 institutions (Table 5). Areas of active investigation included the following: control of gene expression; molecular pathogenesis; protein biosyntheses and compartmentalization; cell development and differentiation; carcinogenesis; development of cellular resistance to cancer; genetic basis of disease; clinical cytogenetics; molecular mechanisms of mutagenesis; and signal transduction.

We have found that the freshman and sophomore year is a critical transition point for attrition in the sciences. With
Table 5. Local and national biomathematics research partnerships with iBLEND

\begin{tabular}{ll}
$\begin{array}{c}\text { NC research and training part- } \\
\text { ners }\end{array}$ & \multicolumn{1}{c}{$\begin{array}{c}\text { Research lab partners } \\
\text { outside NC }\end{array}$} \\
\hline $\begin{array}{l}\text { Appalachian State Univ. Dept. } \\
\text { of Mathematics }\end{array}$ & NIMBioS \\
$\begin{array}{l}\text { UNC-Charlotte } \\
\text { Wake Forest Computational } \\
\text { Biology }\end{array}$ & $\begin{array}{l}\text { MBI at Ohio State University } \\
\text { BioQUEST }\end{array}$ \\
$\begin{array}{l}\text { SHODOR } \\
\text { North Carolina State Graduate } \\
\text { Biomathematics }\end{array}$ & Pittsburgh Supercomputing \\
\hline
\end{tabular}

this early research lab exposure, we found that our students built better interpretive expertise and deeper learning that crossed beyond conventional boundaries between biology, mathematics, computer science, physics, and chemistry disciplines. The central themes of the research projects integrated quantitative molecular biology, modeling, and experimentation at multiple scales. We observed that mathematical and computational analyses complemented the lab bench research by providing deeper understanding of the biological complexity. For instance, our students were exposed to a myriad of modeling tools (such as MATLAB, STELLA, Vensim) that helped to span the range of training from prediction to identification of mechanistic structures. Used appropriately, mathematical models can represent pathways in a physically and biologically realistic manner and generate novel and useful hypotheses (Aldridge et al., 2006). Students gained a better understanding of the governing processes at the molecular, cellular, and organismal level through mathematical analysis of system models and various numerical methods and simulations. By the time our first cohort of students graduated after being exposed to the iBLEND research, they had developed a broad range of mathematical skills such as set theory, linear algebra, differential equations, number theory, numerical analysis, stochastic and deterministic processes, topology, and computational mathematics. Essentially, our students take away analytical argumentative strategies to better understand high-throughput biological data.

The cross-cutting nature of the projects was reinforced by interdisciplinary classroom learning. Both faculty and student teams from different disciplines (biology + mathematics) worked together in tandem and gained a better understanding and broader perspective than single-investigator projects. Faculty and students worked on specific modern biological problems that build upon intuitive understanding using mathematical approaches. Students were compelled to focus on concepts and techniques that bridge mathematical methods with biological systems. In working together, the students learned to bridge language barriers inhibiting interdisciplinary explorations (NRC, 2003). Students were closely involved with faculty mentors and developed crossdisciplinary research skills that enhanced their postgraduate career opportunities. Using systems biology tools, including Ingenuity Pathway Analysis, Mathematica, MATLAB SimBiology, and Stella, students merged data from their lab bench experiments with mathematical models to determine 
Table 6. Seminars, training workshops, and learning modules connected with iBLEND

\begin{tabular}{|c|c|}
\hline Guest seminar/workshop & Topics \\
\hline BioQuest Consortium & $\begin{array}{l}\text { Case-IT/Excel simulations/Tools for } \\
\text { exploratory math }\end{array}$ \\
\hline NESCent & Aspects of evolutionary biology \\
\hline NIMBioS & Biomath curriculum workshops \\
\hline $\begin{array}{l}\text { Pittsburgh Super } \\
\text { Computing }\end{array}$ & $\begin{array}{l}\text { Mathematics and computation and } \\
\text { curriculum development }\end{array}$ \\
\hline MAA-PREP/NCSI & Biomath modeling workshops \\
\hline iPlant Collaborative & $\begin{array}{l}\text { Computational biology for biology } \\
\text { educators }\end{array}$ \\
\hline Shodor/Super-Computing & CSERD and pathway portal of NSDL \\
\hline NC Ag Extension & $\begin{array}{l}\text { Methodologies in soil, water, and } \\
\text { plant analysis }\end{array}$ \\
\hline Wake Forest & $\begin{array}{l}\text { Aspects of computational biophysics } \\
\text { and proteomics }\end{array}$ \\
\hline Ohio State MBI & Aspects of mathematical biology \\
\hline UNCC & $\begin{array}{l}\text { Programming language } \mathrm{R}, \text { PYTHON, } \\
\text { MATLAB }\end{array}$ \\
\hline Wake Forest & $\begin{array}{l}\text { Computational lectures and } \\
\text { development }\end{array}$ \\
\hline
\end{tabular}

how various changes impacted an overall organism and its functions. The students had hands-on training with a myriad of computational tools (e.g., deterministic and stochastic modeling, Monte Carlo simulations, data mining, and data analysis) needed in approaching their projects. Applied mathematical topics including nonlinear dynamical systems (discrete and continuous), partial differential equations, probability and statistics, linear algebra, network theory, numerical analysis, and control theory provided the students with a robust experience with fundamental tools needed to carry out the requisite modeling and analysis.

The central geographic location of NCATSU between Wake Forest University, University of North CarolinaChapel Hill, Duke, and North Carolina State University provides easy implementation for several-day visits and field trips during the academic semesters with collaborating laboratories on our projects. For our students, we leveraged benefit with our partnerships through faculty research collaborations and two-way scholarly exchanges of resources, training, and seminars (Table 6). These established links represent a mutual win/win between NCATSU and R1 partner institutions and laboratories (Table 5). Many of our research collaboration partners have Ph.D. graduate degreetrack programs, and therefore iBLEND is viewed as a productive program to bring in underrepresented minority undergraduates having specific competencies related to mathematical biology. Because iBLEND has a close association with nearby Math-Bio training facilities, students attended and presented seminars related to their projects during the academic year. In addition, iBLEND students presented their research at local and national conferences targeted for mathematical biology education held by NIMBioS, BioQUEST, Appalachian State University, MBI Ohio State, and Southeastern Mathematical Association of America (MAA) Conferences. Other conference presentations each year included MathFest (summer) and the Joint Mathematics Meetings (winter). Progressing to the latter part of their academic careers, as juniors and seniors, they continued with their research and focused on preparation for graduate school. Fundamental during the development of iBLEND was the ongoing partnership with BioQUEST (http://bioquest.org) and SHODOR (http://www.shodor. org). For instance, in summer 2010 the iBLEND will host an upcoming faculty development workshops such as "Computational Biology for Biology Educators," cosponsored by the Super-Computing Education Program and the NSF iPlant Collaborative. These types of partnerships facilitated ready adaptation and use of biomathematical and computational tools, such as those found at the NSF-sponsored Digital Library (NSDL) portals, Excel Simulations and Tools for Exploratory Mathematics (ESTEEM), and Case-It! projects.

\section{Curricular Coherence and Mutual Reinforcement between Research and Classroom Activity}

Departments across campus needed to provide students (and instructors) mechanisms to assess and reflect on learning progress in and out of the classroom (Felder, 1993). Too many of our students in the past emerged from core undergraduate courses without a coherent picture of the critical links between different STEM areas (particularly mathematics and biology). The A\&T biology curriculum specifically requires students to take calculus, chemistry, and biology in the first year, which is where many students fall behind and become disillusioned. To increase the number of students who successfully complete these courses, we provided supplemental instruction for the first- and second-year students (Table 7). Since 2006, we have observed early increases in retention for both math and biology majors (Tables 3 and 4), which may be partially attributed to these iBLEND initiatives. Over this same period, the numbers of students majoring in biology or math have remained fairly constant. As of the time of this paper, graduate rate trends among cohorts are to be determined. In addition, we were aware that outside of the classroom, students learn and communicate with each other through interactive means to share information. Also, iBLEND has been closely associated with the campus Academy for Teaching and Learning (ATL). ATL helped with undergraduate projects across our campus to align departmental curricula, student learning outcomes, pedagogical assessment practices, and evidence of student learning. ATL provided workshops, conferences, short courses, and seminars that supported faculty professional development to enhance teaching effectiveness. The workshops concentrated on student learning outcomes and the design of curricula, teaching methods, and assessment strategies that align with selected learning.

iBLEND faculty mentors were also members of an ongoing campus-based initiative with the Carnegie Academy for the

Table 7. List of courses supported with supplemental instruction and most directly impacted by iBLEND

\begin{tabular}{lll}
\hline Department & Freshman year & Sophomore year \\
\hline Biology & General Biology I & General Biology II \\
Chemistry & Chemistry I & Chemistry II \\
Mathematics & Calculus I & Calculus II \\
\hline
\end{tabular}


Scholarship of Teaching and Learning (CASTL) Institutional Leadership Program and the Wabash National Study of Liberal Arts Education (2009). Faculty from the Departments of Mathematics and Biology used this forum to lead an existing group of faculty team members from the Chemistry, Computer Science, and Physics Departments in an ongoing formative inquiry of quantitative departmental curricula. iBLEND faculty lead departmental groups in the following: 1) mapping out and assessing departmental curricula in terms of coherence with university and departmental student learning outcomes; 2) determining ways to provide evidence of student learning outcome attainment; 3) developing strategies for increasing curricular, pedagogical, and assessment-related coherency in departmental programs; and 4) building community with other departments seeking to improve departmental programs and student learning outcomes through an intentional, coherent, and evidence-based formative process.

As freshmen and sophomores, the students of NCATSU were required to take $12 \mathrm{~h}$ from a cluster of general education courses. This has opened the door for the shaping of existing courses that allow students to be exposed to biomathematics topics and concepts that they would not normally see until later in their academic careers but at a level that was appropriate for their academic backgrounds. As cluster courses are open to all students, it also provided the opportunity to expose students from nonbiology or nonmathematics majors to topics in biomathematics, resulting in a potential improvement in their grades and retention in the related fields. In 2006, NCATSU launched a new course called Analytical Reasoning, which was part of the interdisciplinary general education curriculum required for every freshman undergraduate (2000 students per year). Analytical Reasoning was taught by iBLEND senior personnel using case studies to demonstrate the scientific method and to promote critical thinking about scientific issues. This course engages students in quantitative and logical reasoning processes to prepare them to interpret and solve biological research problems. The scientific method and a variety of analytical approaches were explored, including numerical, graphical, verbal/logical, and algebraic reasoning.

\section{Collaborative Mentoring Network for Research, Learning, and Teaching at the Interfaces}

Our faculty mentors saw mentoring students in research as a part of their normal duties and responsibilities. Key to the mentoring contributions was early interventional measures that enhance the overall science learning experience for stu- dents. Students were assigned two mentors, one in biology and one in mathematics, to help them navigate their way across barriers. Mentors tracked student development (using lab wikis and e-mentoring) and concerns to help make informed decisions and recommendations about opportunities and resources for students. These data were compiled and evaluated with our external evaluation reports.

The iBLEND network enabled collaborations to extend across our campus to provide students (and instructors) with mechanisms to assess and reflect on learning progress in and out of the classroom. The iBLEND initiative built upon existing infrastructure in the Biology and Mathematics Departments, which already have significant capacity with technologylinked dynamic learning environments. As an interactive means to share information, the iBLEND initiative enhanced our existing e-mentoring and learning communities through collaborative lab wikis. Each student's lab wiki had a standard dashboard showing an "about me," recent work and updates, presentations, software use and algorithm code, favorite biomath pages, meeting schedules, and a biomathematics blog with options to link to Facebook and Twitter. While featuring integrated tools for discussion and comments, the wikis were used to encourage social cohesion and reflect the institutional environment and "feel" of NCATSU. All this information was logged and tied in to a formal relational database used for summative and formative evaluations. Our recent alumni students continue to archive and reflect back upon their experiences, and they mentor the next cohort of new students pursuing research. These activities have proved particularly effective at dissemination, outreach, recruitment, and building a sense of community between the program participants and new prospective students.

The research, training, and classroom activities were coupled with mechanisms that reduce barriers to student success. The activities were specifically designed to overcome preconceived notions concerning advanced mathematics or computationally rich courses. This was particularly true for minority students where underrepresentation in research careers goes back to a complex interplay of socioeconomic forces that impact academic achievement (Lowe, 1999). Innovative to our approach was that all of the research projects bring undergraduate researchers to our centrally located Molecular Genetics, Genomics, and Proteomics Laboratory and the Undergraduate Mathematical and Computational Modeling Research Training Laboratory. This infrastructure facilitated collaborative interactions with our many current cutting-edge high-throughput data collection projects. At the same time, the projects also

Table 8. Former A\&T iBLEND (2006-2009) undergraduate students pursuing graduate degrees at the interface of biology and mathematics

\begin{tabular}{cclclc}
\hline & Undergraduate major & Racial identity & Gender & Graduate school & Graduate program \\
\hline 1 & Bio & African American & F & Wake Forest Univ. & Computational Biophysics \\
2 & Bio & African American & M & UNC-Greensboro & Molecular Dynamics \\
3 & Bio & Caucasian & M & Univ. of Maryland & Molecular Biology \\
4 & Math & African American & F & NC A\&T & Computer Science \\
5 & Bio & Caucasian & F A\&T & Molecular Microbiology \\
6 & Bio & Caucasian & M & Mich. State Univ. & Molecular Ecology \\
7 & Bio & African American & F & NC A\&T & Molecular Microbiology \\
8 & Math & African American & F & NC A\&T & Molecular Biophysics \\
\hline
\end{tabular}


reflected the social meaning of science advances and the role of mathematics in society from underrepresented minority perspectives, that further establish meaningful relationships between mathematics and biology (Epstein et al., 1997). As many of our students are first-generation college attendees, there was a wealth of life experiences and personal connections to these projects that give real-world research purpose and provide students with every opportunity to succeed in biomathematics (Muller and Kerbow, 1993).

With the baseline support of other capacity-building programs to support undergraduate research (Table 2), in 2006 the Departments of Biology and Mathematics were awarded with an NSF-supported undergraduate biomath (UBM) award \#0634598. Since 2006, NCATSU has hired eight new junior faculty (five in mathematics, three in biology) with significant biomathematical research portfolios to share with undergraduates in iBLEND. Hence, we currently have a solid cadre of faculty and staff pursuing research and shared discovery at the interface of mathematics and biology. In $<5$ years, faculty individuals supported directly by iBLEND have grown from a faculty of six to more than 20 individuals working closely together at the time this article was written. Moreover, more than 15 undergraduate students have produced numerous biomathematics presentations, posters, and peer-reviewed manuscripts from these laboratories. From 2006-2009, the iBLEND mentored 18 undergraduates. We produced more than eight peer-reviewed journal articles, including undergraduate authors, from this work. The iBLEND students presented over 70 research talks at international, national, and local conferences. Our students received numerous awards for their biomathematics-related research and helped promote diversity with invited talks such as at the International Society for Computational Biology (ISCB) meetings in Stockholm, Sweden, in June 2009. Of our first UBM-funded iBLEND cohort of eight undergraduates (six were African-Americans and/or female), all students are currently enrolled in graduate degrees programs related to biomathematics (Table 8).

\section{Institutional Outcomes}

The emphasis on research has shifted the biology and mathematics major culture, such that students see research as a normal part of their matriculation and not just a special activity for a select few. As an immediate outcome of efforts described, an increasing number of undergraduates have actively engaged in hands- and minds-on research, and many more underrepresented students from our campus are motivated to continue graduate research. Hence, the culture has shifted in that more students anticipate research as a normal part of matriculation and not as a special activity for a select number of students. As a tangible outcome, faculty view mentoring research students as a part of their normal duties and responsibilities and one that brings prestige to the student, the faculty, and the university. Potential NCATSU students now recognize this university as an institution that prepares students for research careers. Consequently, NCATSU has enhanced its recruitment of quality students into science departments. Significant internship participation (more than 80 biology and mathematics undergraduates per year) has been an integral contributor to the success of our model for success. Our pipeline model has directly fostered a significant increase in the number of undergraduates conducting research without the distraction of outside jobs. Our model has provided a forum for instructors and students to discuss research beyond the classroom by demonstrating practical uses of scientific concepts and techniques to underclassman and the university as a whole. Importantly, our pipeline for bioscience majors has enhanced science career awareness and provided outstanding networking opportunities for both students and faculty. To that end, our iBLEND model has leveraged existing resources into several strategic advantages for recruiting and retaining quality minority students.

\section{ACKNOWLEDGMENTS}

The iBLEND work was supported by NSF Interdisciplinary Training for Undergraduates in Biological and Mathematical Sciences (UBM) Grant No. 0634598. We thank Drs. Mary A. Smith, Goldie S. Byrd, and Guoqing Tang for their vital encouragement and support of this initiative.

\section{REFERENCES}

Aldridge, B. B., Burke, J. M., Lauffenburger, D. A., and Sorger, P. K. (2006). Physicochemical modelling of cell signalling pathways. Nat. Cell Biology 8, 1195-1203.

Carnegie Classification of Institutions of Higher Education (2005). A Technical Report, Menlo Park, CA: Carnegie Publications.

Epstein, J., Coates, L., Salinas, K., Sanders, M., and Simon, B. (1997). School, Family, and Community Partnerships: Your Handbook for Action, Thousand Oaks, CA: Corwin Press.

Felder, R. M. (1993). Reaching the second tier-learning and teaching styles in college science education. J. Coll. Sci. Teach. 23, 286-290.

Gross, L. (1994). Quantitative training for life-science students. BioScience 44,59

Jungck, J. R. (2005). Challenges, connection, complexities: educating for collaboration. In Math \& Bio 2010: Linking Undergraduate Disciplines, ed. L.A. Steen, Washington DC: Mathematical Association of America.

Lowe Jr., E. (1999). Promise and Dilemma: Perspectives on Racial Diversity and Higher Education, Princeton: Princeton University Press.

McElroy, E., and Armesto, M. (1998). TRIO and Upward Bound: history, programs, and issues? Past, present, and future. J. Negro Ed. 67, 373-380.

Mervis, J. (2003). Workforce diversity: NSF, academics told to act as if they mean it. Science 301, 1030-1031.

Moses, R. P., and Cobb Jr., E. (2001). Radical Equations: Math Literacy and Civil Rights, Boston, MA: Beacon Press.

Muller, C., and Kerbow, D. (1993). Parent involvement in the home, school, and community. In: Parents, Their Children, and Schools, ed. B. Schneider \& J. S. Coleman, Boulder, CO: Westview Press, 13-42.

National Research Council (NRC) (2003). BIO 2010: Transforming Undergraduate Education for Future Research Biologists. Washington, DC: National Academies Press.

NRC (2007). Understanding Interventions That Encourage Minorities to Pursue Research Careers: Summary of a Workshop. Washington DC: National Academies Press.

Wabash National Study of Liberal Arts Education (2009). A largescale, longitudinal study to investigate critical factors that affect the outcomes of liberal arts education. www.liberalarts.wabash.edu/ nationalstudy. 